\title{
Radiological Impact of 1996 Operations at the Savannah River Site
}

$$
\text { CONF-9711117-- }
$$

by

G. T. Jannik

Westinghouse Savannah River Company

Savannah River Site

Aiken, South Carolina 29808

A document prepared for 43RD ANNUAL COONFERENCE ONBIOASSAY, ANALYTICAL AND

ENVIRONMENTAL RADIOCHEMISTRY at Charleston, SC, USA from 11/9/97 - 11/13/97.

\section{DOE Contract No. DE-AC09-89SR18035}

This paper was prepared in connection with work done under the above contract number with the U.S.

Department of Energy. By acceptance of this paper, the publisher and/or recipient acknowledges the U.S. Government's right to retain a nonexclusive, royalty-free license in and to any copyright covering this paper, along with the right to reproduce and to authorize others to reproduce all or part of the copyrighted paper.

EMTIRIEUTION OF THIS DOCUMENT IS UALIMTTES

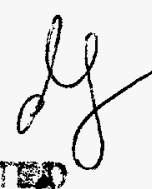




\section{DISCLAIMER}

This report was prepared as an account of work sponsored by an agency of the United States Government. Neither the United States Government nor any agency thereof, nor any of their employees, makes any warranty, express or implied, or assumes any legal liability or responsibility for the accuracy, completeness, or usefulness of any information, apparatus, product, or process disclosed, or represents that its use would not infringe privately owned rights. Reference herein to any specific commercial product, process, or service by trade name, trademark, manufacturer, or otherwise does not necessarily constitute or imply its endorsement, recommendation, or favoring by the United States Government or any agency thereof. The views and opinions of authors expressed herein do not necessarily state or reflect those of the United States Government or any agency thereof.

This report has been reproduced directly from the best available copy.

Available to DOE and DOE contractors from the Office of Scientific and Technical Information, P. O. Box 62, Oak Ridge, TN 37831; prices available from (423) 576-8401.

Available to the public from the National Technical Information Service, U. S. Department of Commerce, 5285 Port Royal Road, Springfield, VA 22161. 


\section{DISCLAIMER}

Portions of this document may be illegible electronic image products. Images are produced from the best available original document. 


\title{
Radiological Impact of 1996 Operations at the Savannah River Site (U)
}

\author{
G.T. Jannik
}

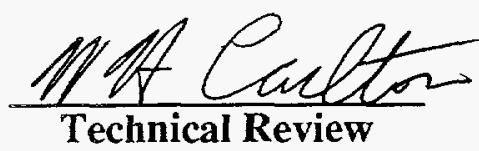

$\frac{\text { DBmare. Sledenor }}{\text { Derivative Classifier }}$

August, 1997

Westinghouse Savannah River Company

Savannah River Site Aiken, SC 29808

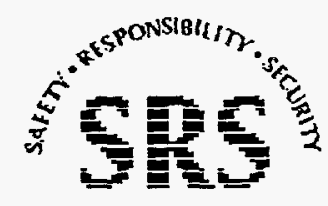

SAVANNAH RIYER SITE 


\section{RADIOLOGICAL IMPACT OF 1996 OPERATIONS AT THE SAVANNAH RIVER SITE}

\section{SUMMARY}

During 1996, atmospheric releases of tritium from the Savannah River Site (SRS) were dramatically less than in 1995. The total amount of atmospheric tritium released during 1996 was 55,300 curies, which was $43 \%$ less that the 1995 total of 96,700 curies. Of the total tritium released, 40,100 curies were tritium oxide, this was $27 \%$ less than the 1995 atmospheric tritium oxide release total of 55,000 curies.

Releases of radioactive liquid effluents from SRS decreased during 1996. Liquid releases of tritium (which constitutes more than $99 \%$ of the total radioactivity released to the Savannah River) in $1996(8,950$ curies) were about $21 \%$ less than during 1995 ( 11,400 curies).

In 1996, the potential dose to the maximally exposed individual from SRS atmospheric releases was estimated to be $0.05 \mathrm{mrem}$ (see Table 1). This dose is $0.5 \%$ of the U.S. Environmental Protection Agency (EPA) and U.S. Department of Energy (DOE) air pathway dose standard of $10 \mathrm{mrem} / \mathrm{year}$.

The 1996 maximally-exposed-individual air pathway dose was about $17 \%$ lower than the 1995 air pathway dose of 0.06 mrem primarily because of the $27 \%$ decrease in tritium oxide atmospheric releases.
The 80-kilometer-radius population of 620,100 people potentially received a collective dose of 2.8 person-rem from SRS atmospheric radioactive releases. The 1996 collective dose was about $20 \%$ lower than the 1995 collective dose of 3.5 person-rem.

The potential dose to the maximally exposed individual from 1996 SRS liquid radioactive releases was estimated to be 0.14 mrem (Table 1). This dose is $0.14 \%$ of the DOE all-pathway dose standard of $100 \mathrm{mrem} / \mathrm{year}$.

The 1996 liquid pathway dose was about the same as the 1995 dose, even though total liquid tritium releases decreased $21 \%$. This happened because there was a $13 \%$ decrease in the Savannah River's effective flow rate during 1996, resulting in less dilution.

At the Beaufort-Jasper Water Treatment Plant, and at the City of Savannah Industrial and Domestic Water Supply Plant, the 1996 maximum potential drinking water dose was estimated to be $0.06 \mathrm{mrem}$, which is $1.5 \%$ of the DOE and EPA drinking water pathway dose standard of $4 \mathrm{mrem} / \mathrm{year}$.

The collective dose from SRS liquid releases during 1996 was estimated at 2.2 person-rem. The major exposure pathway to the population was drinking water, with tritium accounting for more than $70 \%$ of the total collective dose.

Table 1. Five-Year History of Offsite Dose from SRS Operations

\begin{tabular}{|c|c|c|c|c|c|}
\hline \multirow{2}{*}{\multicolumn{6}{|c|}{ Atmospheric Releases }} \\
\hline & & & & & \\
\hline Max. Exposed Individual (mrem) & 0.09 & 0.11 & 0.09 & 0.06 & 0.05 \\
\hline Population (person-rem) & 6.4 & 7.6 & 6.3 & 3.5 & 2.8 \\
\hline \multicolumn{6}{|l|}{ Liquid Releases } \\
\hline Max. Exposed Individual (mrem) & 0.13 & 0.14 & 0.14 & 0.14 & 0.14 \\
\hline Drinking Water (Beaufort-Jasper) & 0.07 & 0.04 & 0.05 & 0.04 & 0.06 \\
\hline Drinking Water (Savannah) & 0.09 & 0.05 & 0.06 & 0.05 & 0.06 \\
\hline Population (person-rem) & 2.5 & 1.5 & 1.7 & 1.6 & 2.2 \\
\hline
\end{tabular}




\section{ATMOSPHERIC RELEASES}

The 1996 atmospheric radioactive release quantities used as source terms in SRS dose calculations are shown in Table 2 (from Amett, 1997). For dose calculation purposes, releases of unidentified beta emitters were summed with strontium-89,90 releases and accounted for $98 \%$ of the total strontium89,90 reported. Likewise, unidentified alpha emitters were summed with plutonium-239 releases and accounted for $43 \%$ of the total plutonium-239 reported.

Sources of diffuse and fugitive (nonpoint) radiological emissions to the atmosphere have been included in the SRS source terms since 1991. Nonpoint sources include seepage basins, burial grounds, open pits, and tanks. These sources are included in SRS's annual National Emission Standard for Hazardous Air Pollutants (NESHAP) report. Except for cesium-137 and rutheneum-106, doses resulting from atmospheric releases were not significantly influenced by the addition of these nonpoint sources.

\section{Tritium}

Tritium, in its elemental and oxide forms, accounts for more than $90 \%$ of the total amount of airborne radioactivity released from the site. During 1996, an estimated 55,300 curies of tritium were released to the atmosphere; this was about $43 \%$ less than the 96,700 curies released during 1995 .
The radiation dose received by people exposed to airborne tritium is dependent upon the amount released as tritium oxide; tritium in its elemental form is biologically inactive.

During 1996, the amount of tritium oxide released was about 40,100 curies; this was $27 \%$ less than the 55,000 curies released during 1995 and was the lowest reported since 1955. Tritium oxide releases accounted for about $68 \%$ of the dose to the maximally exposed individual and more than $74 \%$ of the collective dose to the 80 -kilometer-radius population of 620,100 people.

Figure 1 presents a 10-year history of atmospheric tritium releases from SRS. Because of changes in the site's mission and the subsequent shutdown of all the reactor facilities, the amount of tritium oxide released from the site declined steadily from 1987 through 1992. In 1993, the increase in tritium oxide released was attributed to increased loading and unloading of tritium reservoirs in the Tritium facilities. These increased operations, especially the reservoir unloading operations, were a result of the country's nuclear reduction program following the end of the Cold War. The $43 \%$ decrease in tritium releases during 1996, as compared to 1995 , is attributed to (1) reduced throughput in the tritium facilities; (2) reduced maintenance and layup work in the reactor areas; and (3) continued improvements in tritium reprocessing operations at the recently completed Replacement Tritium Facility.

Figure 1. Ten-Year History of Atmospheric Releases from SRS

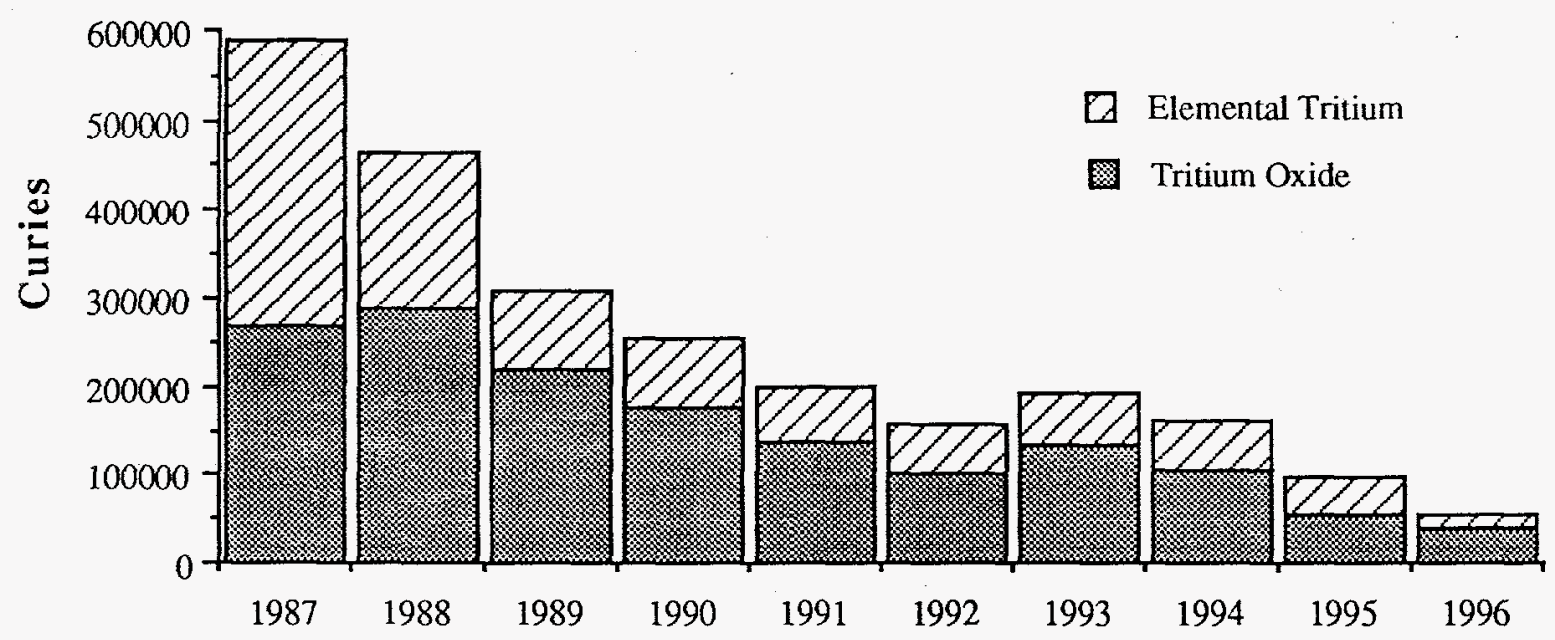


Table 2. 1996 SRS Radioactive Atmospheric Releases by Source and Radionuclide

\begin{tabular}{|c|c|c|c|c|c|c|c|}
\hline \multirow[b]{2}{*}{ Radionuclide } & \multicolumn{7}{|c|}{ Curies (a) } \\
\hline & Reactors & $\begin{array}{l}\text { Separa- } \\
\text { tions(b) }\end{array}$ & $\begin{array}{c}\text { Reactor } \\
\text { Materials }\end{array}$ & $\begin{array}{l}\text { Heavy } \\
\text { Water }\end{array}$ & SRTC(c) & $\begin{array}{l}\text { Diffuse and } \\
\text { Fugitive(d) }\end{array}$ & Total \\
\hline \multicolumn{8}{|c|}{ GASES AND VAPORS } \\
\hline$H-3$ (oxide) & $1.10 E+04$ & $2.85 E+04$ & & $3.29 E+02$ & & $2.23 E+02$ & $4.01 E+04$ \\
\hline H-3 (elem) & & $1.51 E+04$ & & & & & $1.51 E+04$ \\
\hline H-3 Total & $1.10 E+04$ & 4.37E+04 & & $3.29 E+02$ & & $2.23 E+02$ & $5.53 E+04$ \\
\hline C-14 & & $8.11 E+00$ & & & & 5.88E-09 & $8.11 E+00$ \\
\hline $\mathrm{Kr}-85$ & & $5.47 E+03$ & & & & & $5.47 E+03$ \\
\hline $\mathrm{Xe}-135$ & & & & & $1.20 E-03$ & & $1.20 \mathrm{E}-03$ \\
\hline $1-129$ & & $1.04 \mathrm{E}-02$ & & & & 3.83E-06 & $1.04 \mathrm{E}-02$ \\
\hline $\mid-131$ & & 5.74E-05 & & & 2.98E-05 & & 8.72E-05 \\
\hline $1-133$ & & & & & $5.94 \mathrm{E}-04$ & & $5.94 \mathrm{E}-04$ \\
\hline \multicolumn{8}{|l|}{ PARTICULATES } \\
\hline Co-57 & & 5.76E-09 & & & & & 5.76E-09 \\
\hline Co-60 & & $3.85 E-07$ & & & $8.55 E-06$ & 4.71E-07 & 9.41E-06 \\
\hline $\mathrm{Ni}-59$ & & & & & & 2.51E-08 & 2.51E-08 \\
\hline $\mathrm{Zn}-65$ & & & & . & & $1.46 E-16$ & $1.46 E-16$ \\
\hline Se-79 & & & & & & $2.47 E-08$ & 2.47E-08 \\
\hline Sr-89,90 (e) & $1.05 E-03$ & $1.46 \mathrm{E}-03$ & $4.04 E-05$ & $9.48 E-05$ & (g) & $4.75 E-04$ & $3.12 E-03$ \\
\hline $\mathrm{Nb}-95$ & & & & & & $1.55 \mathrm{E}-15$ & $1.55 E-15$ \\
\hline $\mathrm{Zr}-95$ & & & & & & 2.13E-05 & $2.13 E-05$ \\
\hline Tc-99 & & & & & & 2.65E-08 & $2.65 E-08$ \\
\hline$R u-106$ & & $9.18 E-07$ & & & & $7.00 \mathrm{E}-02$ & 7.00E-02 \\
\hline$S n-126$ & & & & & & $6.79 E-09$ & 6.79E-09 \\
\hline $\mathrm{Sb}-125$ & & 2.61E-07 & & & & $2.28 E-04$ & $2.28 \mathrm{E}-04$ \\
\hline Cs-134 & & $1.97 E-07$ & & & & $2.49 E-15$ & $1.97 \mathrm{E}-07$ \\
\hline Cs-137 & $1.76 \mathrm{E}-05$ & $4.82 E-04$ & $3.94 E-07$ & $1.11 E-06$ & $1.22 E-06$ & $4.33 E-03$ & $4.83 E-03$ \\
\hline $\mathrm{Ce}-144$ & & 6.77E-07 & & & & 7.36E-06 & 8.04E-06 \\
\hline$P m-147$ & & & & & & $6.75 E-06$ & $6.75 E-06$ \\
\hline Eu-154 & & 1.87E-07 & & & & $6.42 E-06$ & 6.61E-06 \\
\hline Eu-155 & & 8.33E-07 & & & & $1.66 E-06$ & 2.49E-06 \\
\hline Th-232 & & & & & & $1.28 \mathrm{E}-08$ & $1.28 E-08$ \\
\hline $\mathrm{Pa}-231$ & & & & & & $1.00 \mathrm{E}-09$ & $1.00 E-09$ \\
\hline U-233 & & & & & & $1.62 E-08$ & $1.62 E-08$ \\
\hline U-234 & & $2.44 E-04$ & $6.81 E-06$ & & & 2.93E-07 & 2.51E-04 \\
\hline U-235 & & 4.67E-05 & $1.06 E-06$ & & & 4.10E-05 & $8.88 E-05$ \\
\hline U-236 & & & & & & 5.79E-08 & 5.79E-08 \\
\hline U-238 & & $1.37 E-03$ & 1.09E-06 & & & $1.35 \mathrm{E}-06$ & $1.37 E-03$ \\
\hline Np-237 & & & & & & $4.66 \mathrm{E}-08$ & $4.66 E-08$ \\
\hline Np-239 & & & & & & $2.17 E-07$ & 2.17E-07 \\
\hline $\mathrm{Pu}-238$ & & 4.79E-04 & 2.23E-09 & & & $5.19 E-06$ & $4.84 E-04$ \\
\hline $\mathrm{Pu}-239$ (f) & $6.74 E-05$ & $2.65 \mathrm{E}-04$ & 2.78E-05 & 6.39E-06 & $6.67 E-06$ & $1.83 E-04$ & 5.57E-04 \\
\hline Pu-240 & & & & & & $2.11 E-07$ & $2.11 \mathrm{E}-07$ \\
\hline $\mathrm{Pu}-241$ & & & & & & 3.75E-06 & $3.75 E-06$ \\
\hline$A m-241$ & & $1.27 E-05$ & $1.06 \mathrm{E}-08$ & & & $4.20 E-07$ & $1.31 \mathrm{E}-05$ \\
\hline$A m-243$ & & & & & & $1.76 E-05$ & $1.76 \mathrm{E}-05$ \\
\hline $\mathrm{Cm}-242$ & & & & & & $2.03 E-16$ & $2.03 E-16$ \\
\hline $\mathrm{Cm}-244$ & & 4.47E-06 & $2.43 E-09$ & & & $1.28 E-04$ & $1.32 E-04$ \\
\hline $\begin{array}{l}\text { a. One curie equals } \\
\text { b. Includes separati } \\
\text { c. Savannah River } \\
\text { d. Estimated releas } \\
\text { e. Includes unidenti } \\
\text { f. Includes unidentifi } \\
\text { g. There were no un }\end{array}$ & $\begin{array}{l}10 \text { Becquerels. } \\
\text { raste managemer } \\
\text { logy Center } \\
\text { n minor unmonitc } \\
\text { ta emissions. } \\
\text { ha emissions. } \\
\text { ied emissions fro }\end{array}$ & $\begin{array}{l}\text { and tritium facil } \\
\text { diffuse and fo } \\
\text { SRTC. }\end{array}$ & $\begin{array}{l}\text { ies } \\
\text { itive sources }\end{array}$ & & & & \\
\hline
\end{tabular}




\section{Other Radioactive Gases and Vapors}

Besides tritium, the only other radioactive gases and vapors measured in SRS process air effluents during 1996 were small quantities of iodine-129, iodine-131, iodine-133, and xenon-135 (Table 2). Though they are fission products and have relatively short half-lives, iodine-131, iodine-133, and xenon-135 were detectable in air effluents because of the spontaneous fissioning of californium-252 stored at SRS (Kantelo and Crandall, 1993).

Because of the difficulty of sampling, carbon14 , krypton-85, and fission product tritium are not readily detectable in Separations area effluents. Therefore, atmospheric releases of these radionuclides are calculated based on annual production rates in the Separations facilities.

Of this group, only iodine- 129 had significant potential impacts on offsite doses. Iodine-129 releases accounted for $11 \%$ of the dose to the maximally exposed individual and $6.9 \%$ of the collective dose. All other radioactive gases and vapors (besides tritium) accounted for less than $5 \%$ of potential doses.

A 10-year history of iodine-129 atmospheric releases is shown in Figure 2. During 1996, releases of iodine-129 increased slightly due to the resumption of limited separation operations in the Separations facilities.

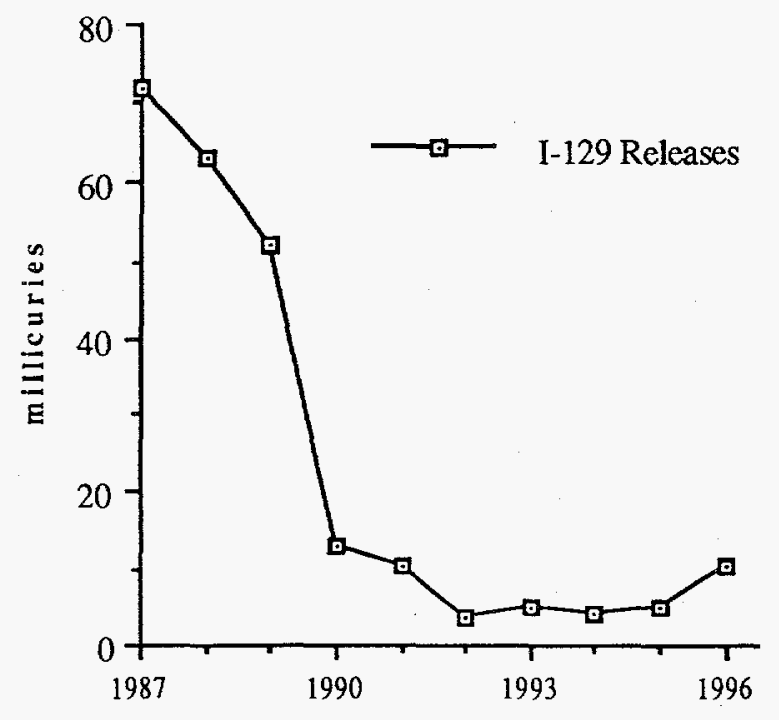

Figure 2. I-129 Airborne Releases (1987-1996)

\section{Radioactive Particulates}

In Table 2, the radioactive particulates released from SRS are shown by facility. During 1996, the only radioactive particulates that accounted for more than $1 \%$ of the potential offsite dose to the maximally exposed individual were ruthenium-106 $(5.0 \%)$, cesium-137 (1.5\%), uranium-238 (1.1\%), plutonium-238 (2.3\%), and plutonium-239 (5.0\%).

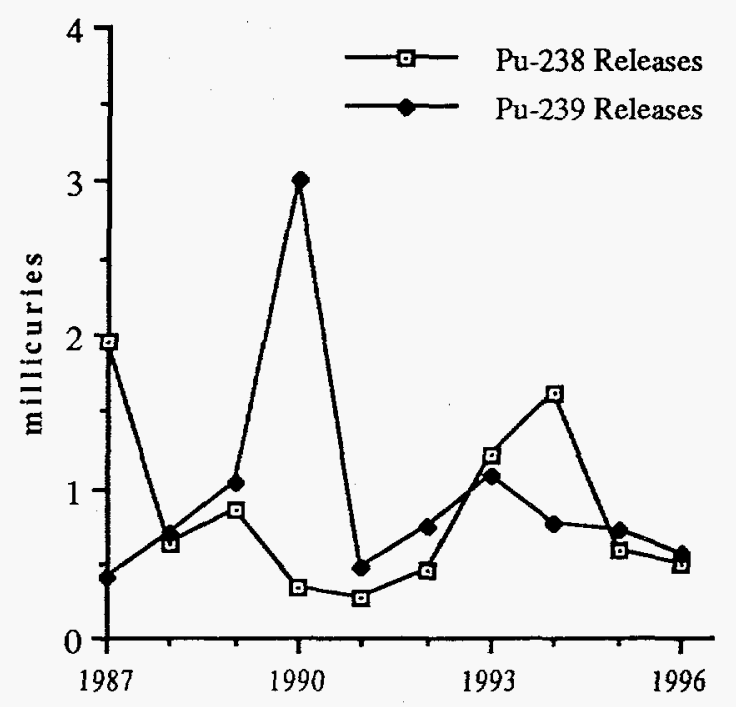

Figure 3. Pu Airborne Releases (1987-1996)

Figure 3 shows the 10-year trend of the plutonium-238 and plutonium-239 airborne releases. As can be seen, plutonium-238 releases had been increasing over the past few years, but decreased in 1995 and 1996 primarily because of the completion of the fuel fabrication work for NASA's Cassini mission. Plutonium-239 releases remained at historically low levels.

Estimated diffuse and fugitive emissions of ruthenium-106 increased two orders of magnitude from 1995 (1.8 E-04 curie) to 1996 (7.0 E-02 curie), which accounted for about $5 \%$ of the 1996 maximally-exposedindividual dose. Estimated diffuse and fugitive emissions of cesium-137 decreased by a factor of 3 from 1995 (1.4 E-02 curie) to 1996 (4.3 E-03 curie), and accounted for less than $1.5 \%$ of the 1996 potential dose. 


\section{LIQUID RELEASES}

The 1996 liquid radioactive release quantities used as source terms in SRS dose calculations are shown in Table 3 (Amett, 1997). For dose calculation purposes, releases of unidentified beta emitters were summed with strontium-89, 90 releases and accounted for about $60 \%$ of the total strontium-89,90 reported. Likewise, unidentified alpha emitters were summed with plutonium-239 releases and accounted for more than $99 \%$ of the total plutonium-239 reported.

Data from continuously monitored liquid effluent discharge points are used, in conjunction with measured groundwater migration releases from closed site seepage basins and SWDF, to quantify the total amount of radioactive material released to the Savannah River from SRS operations.

\section{Tritium}

Tritium, in the oxide form, accounts for more than $99 \%$ of the total amount of aqueous radioactivity released from the site and for about $41 \%$ of the potential dose to the maximally exposed individual. Because of the mobility of tritium in water and the quantity of the radionuclide released during the years of SRS operations, an annual tritium balance is performed and is evaluated using the following methods of calculation:
- tritium releases from process effluent discharge points and measured migration from closed site seepage basins and SWDF (direct releases)

- tritium transport in onsite streams, measured at the last sampling point (near the mouth of each stream) prior to entry in the Savannah River (stream transport)

- tritium transport in the Savannah River, measured near River Mile 120 (by the U.S. Highway 301 bridge) (river transport)

Figure 4 shows a 10-year history of direct releases, stream transport, and river transport as determined by the Environmental Monitoring Section (EMS) at SRS. As shown, there is close agreement among the three methods.

To maintain conservatism, the 1996 river transport tritium release total of 8,950 curies, which was the highest of the three alternative methods, was used in the dose calculations. This was $21 \%$ less than the 1995 liquid tritium source term of 11,400 curies.

The amount of tritium released directly from SRS process areas in 1996 was 949 curies, which was $29 \%$ less than the 1995 total of 1,340 curies and is just $11 \%$ of the estimated total tritium (river transport value) reaching the Savannah River. The remaining $89 \%$ came from migration releases to onsite streams.

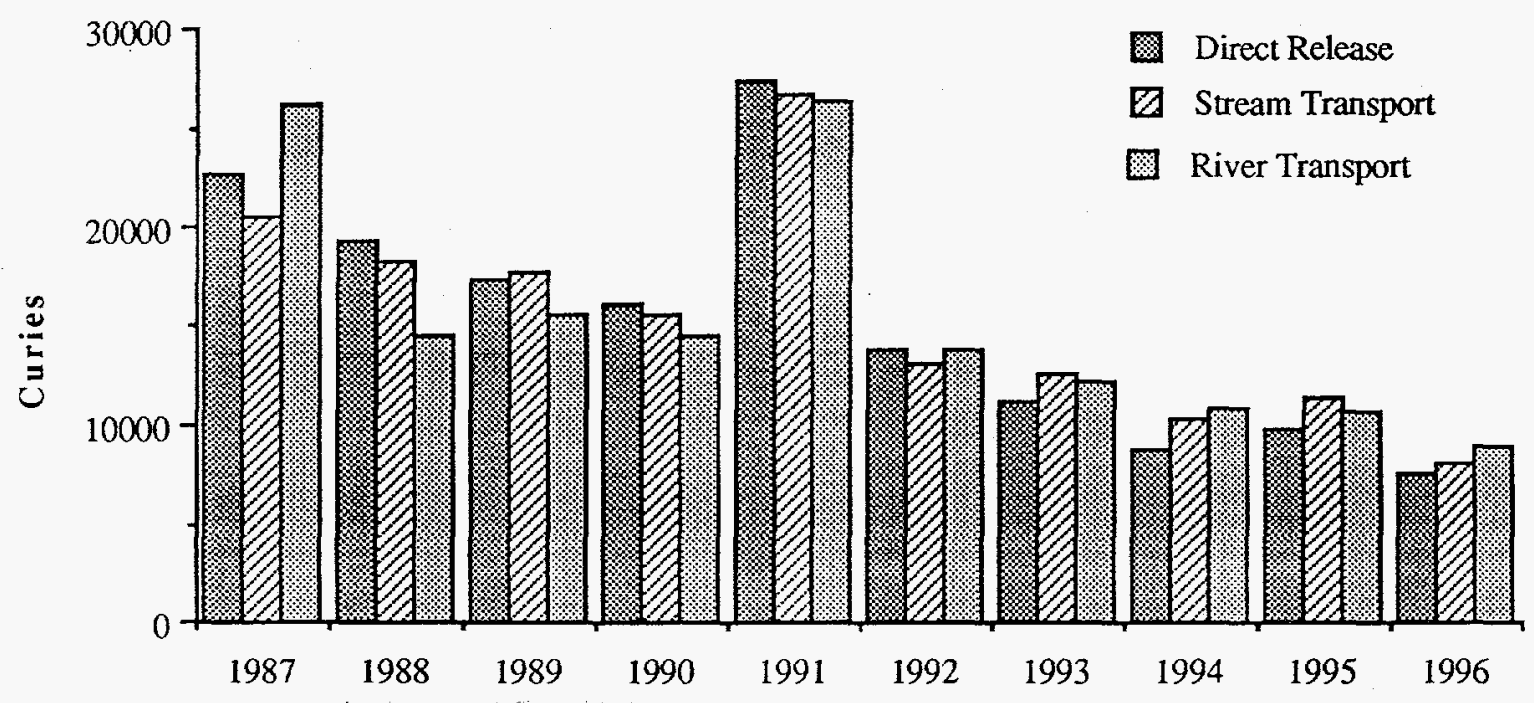

Figure 4. Liquid Tritium Releases from SRS (1987-1996) 
Table 3. 1996 SRS Radioactive Liquid Releases by Source and Radionuclide

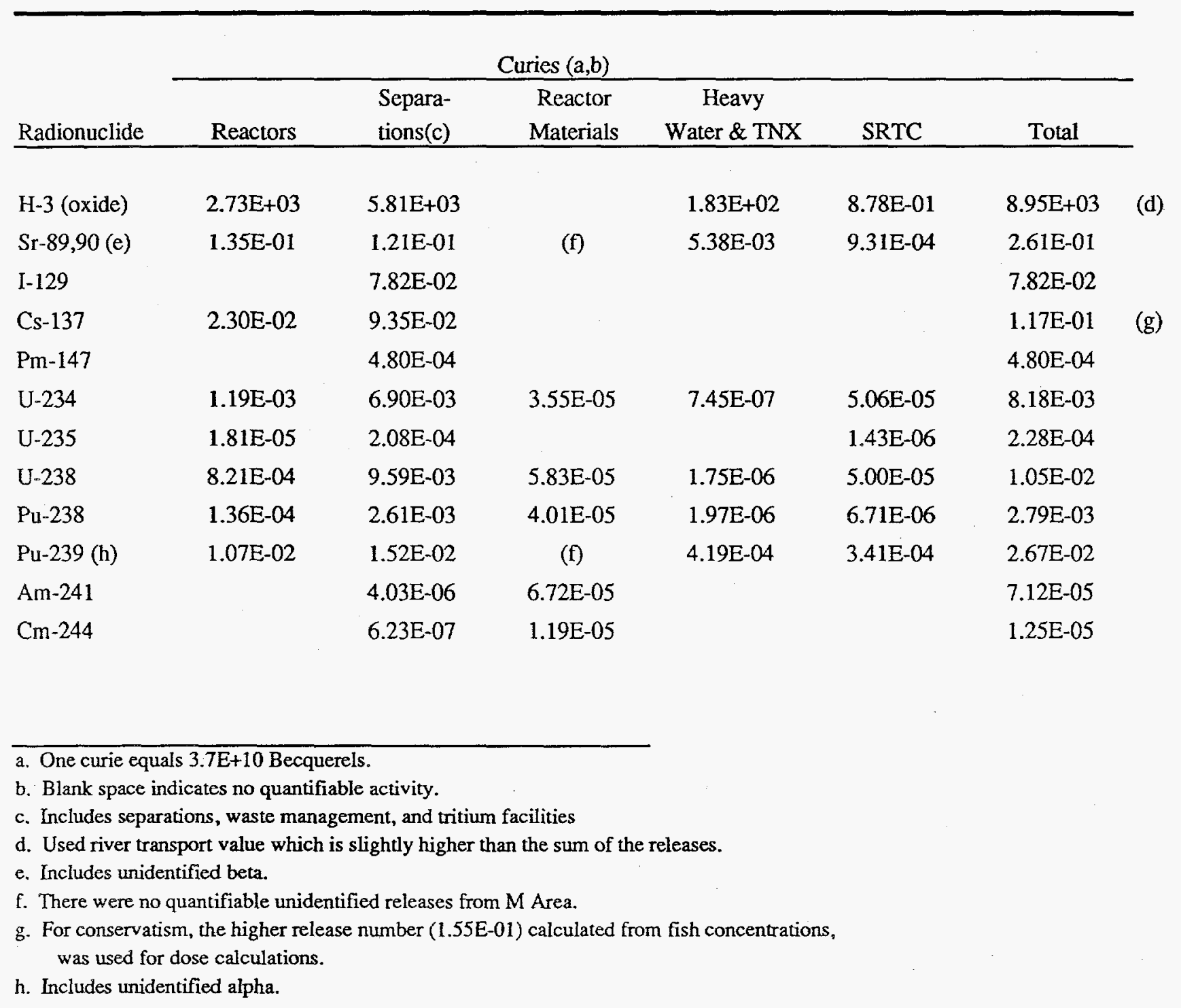




\section{Cesium-137}

In 1996 , over $43 \%$ of the potential liquid pathway dose to the maximally exposed individual resulted from the ingestion of cesium-137, mainly from the consumption of Savannah River fish. The dose from the cesium-137 in fish is based on the analysis of fish caught near River Mile 120. This is accomplished in the LADTAPII code by substituting a cesium-137 source term that would result in the measured concentration in the River Mile 120 fish, based on a sitespecific bioaccumulation factor of 3,000.

Using this method, it was estimated that the amount of cesium-137 released from SRS during 1996 was 0.155 curie, which is 1.3 times more than the measured release value of 0.117 curie (Table 3 ). This indicates either some movement of fish from site streams to the main channel of the river or a source of release to the river other than measured liquid effluents, possibly from streambed and swamp desorption and/or migration from SWDF and closed site seepage basins.

Figure 5 shows a 10-year history of SRS cesium-137 liquid release totals (determined from River Mile 120 fish concentrations). As can be seen, the 1996 release total was about $23 \%$ less than the 1995 total.

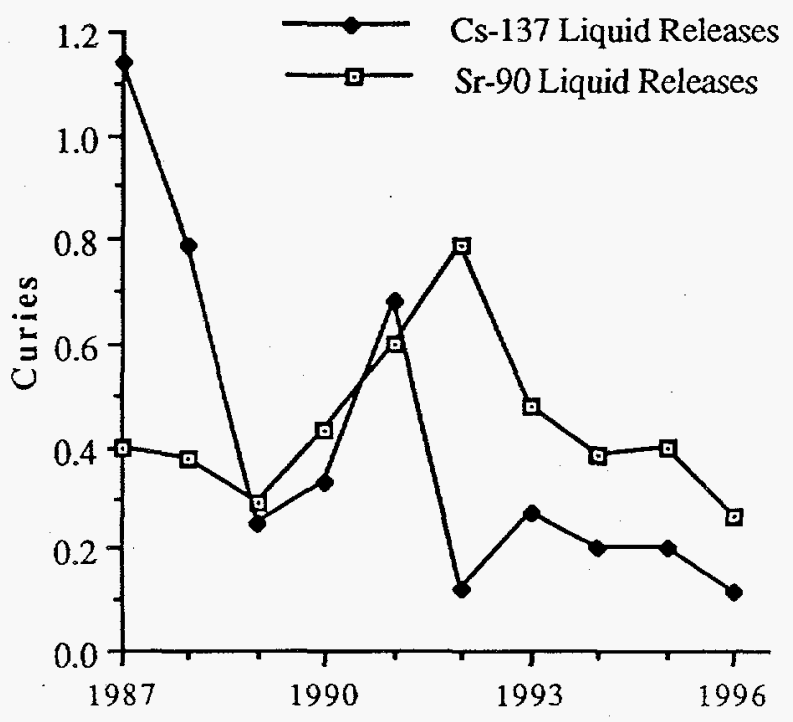

Figure 5. Cs and Sr Liquid Releases (1987-1996)

\section{Other Aqueous Radionuclides}

Besides tritium and cesium-137, the only aqueous radionuclides released from SRS during 1996 which accounted for more than $1 \%$ of the maximally-exposed-individual dose, were strontium-89,90 (4.2\%), iodine-129 $(2.1 \%)$, and plutonium-239 (8.8\%).

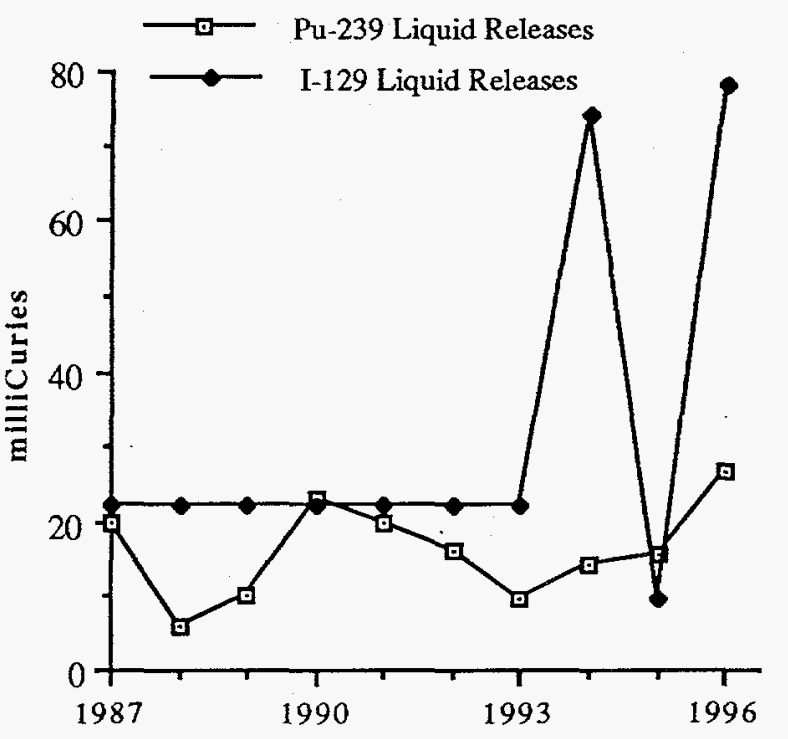

Figure 6. Pu and I Liquid Releases (1987-1996)

A 10-year history of strontium-89,90 liquid releases, which includes unidentified beta, is shown with cesium-137 releases in Figure 5. The strontium-89,90 releases generally follow the same trend as the cesium-137 releases. The 1996 strontium-89,90 release total of 0.26 curie is about 35\% less than the 1995 release.

Figure 6 shows a 10-year history of site liquid releases of plutonium-239. The 1996 plutonium-239 release total of 27 millicuries, which is comprised of more than $99 \%$ unidentified alpha, was $69 \%$ more than the 1995 total. Most of the increase was caused by unexplained spikes in 2 weekly samples from $\mathrm{K}$-Area and 5 weekly samples from F-Area.

A 10-year history of iodine-129 liquid releases is shown with plutonium-239 releases in Figure 6. Prior to 1994, migration releases of iodine-129 were estimated based on a limited study completed in 1980 (Kantelo, 1987). Since 1994, no general trend can yet be determined from the iodine-129 migration release totals. 


\section{AIR PATHWAY DOSES}

All potential air pathway dose estimates were calculated using derivatives of the Nuclear Regulatory Commission (NRC) computer programs XOQDOQ (Sagendorf, 1982) and GASPAR (Eckerman, 1980). SRTC's versions of these atmospheric transport and dosimetry codes, MAXIGASP and POPGASP, provide dose predictions for a maximally exposed individual and for the population within 80 kilometers of the center of SRS.

For 1996, all potential doses from release of radioactivity to the atmosphere were calculated using the meteorological database for H-Area, which was determined for the period 19871991 (Parker et al, 1992). The potential collective dose was based on an 80-kilometerradius population of 620,100 people.

\section{Atmospheric Concentrations}

The MAXIGASP code calculates average and maximum concentrations of all released radionuclides at the SRS boundary. These calculated concentrations are used for dose determinations, rather than the measured concentrations, because most radionuclides released from the site cannot be measured (using standard methods) in the air samples collected at the site perimeter. However, tritium oxide concentrations at the site perimeter can usually be measured, using standard analytical methods, and are compared with the calculated values as a verification of the dispersion models.

The average tritium oxide concentration in air measured at the 14 site perimeter locations during 1996 was $11 \mathrm{pCi} / \mathrm{m}^{3}$. This value compares favorably with the MAXIGASP calculated value of $11 \mathrm{pCi} / \mathrm{m}^{3}$. The maximum tritium oxide concentration measured in air at the site perimeter was $19 \mathrm{pCi} / \mathrm{m}^{3}$, which occurred at the D-Area location. This also compares favorably with the MAXIGASP predicted maximum value of $23 \mathrm{pCi} / \mathrm{m}^{3}$.

Figure 7 shows a 10-year history of measured versus MAXIGASP calculated average tritium oxide concentrations in air at the SRS boundary. These data show that the calculated site-perimeter tritium oxide concentrations are conservative in that they are consistently more than or equal to the measured values and, therefore, are appropriate for use in dose determinations.

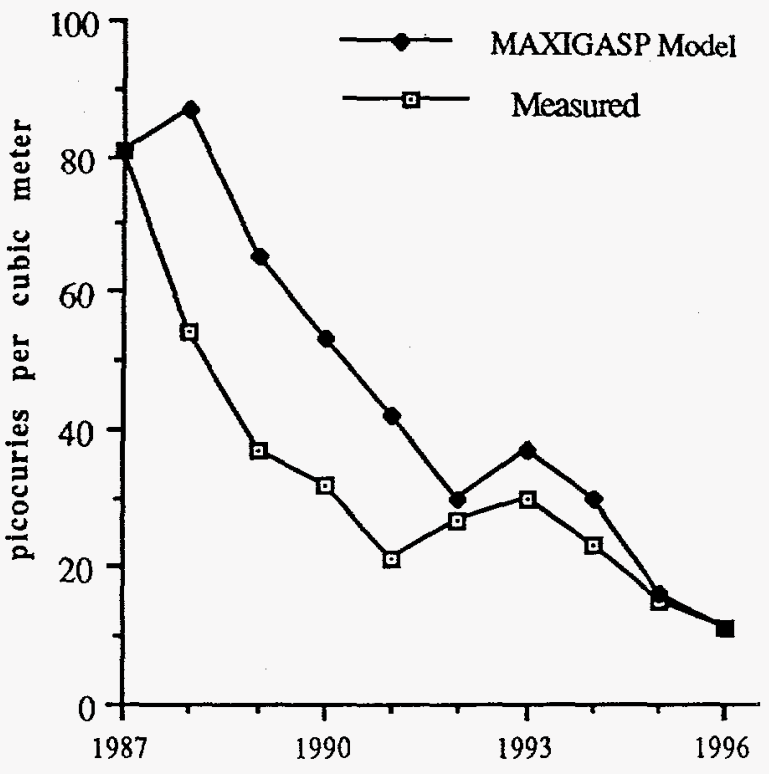

Figure 7. Measured versus Modeled Average Site-Perimeter Tritium Concentrations

Potential Air Pathway Doses for 1996

The 1996 potential airborne pathway doses from SRS releases are shown in Table 4 by pathway and by radionuclide (Arnett, 1997).

\section{Maximally Exposed Individual Dose}

The maximum potential air pathway dose to an individual located at the site perimeter is calculated using MAXIGASP, and is based on maximum radionuclide concentrations and maximum usage and consumption rates.

In 1996, the estimated dose to the maximally exposed individual was $0.05 \mathrm{mrem}$, which is $0.5 \%$ of the EPA 40 CFR 61 and DOE Order 5400.5 standard of 10 mrem per year. This dose was approximately $17 \%$ less than the 1995 dose of $0.06 \mathrm{mrem}$, primarily because of the $27 \%$ decrease in atmospheric tritium oxide releases from 1995 to 1996.

As shown in Table 4 , tritium oxide releases accounted for $68 \%$ of the dose to the maximally exposed individual. The critical pathways through which the maximally exposed individual received the majority of dose were inhalation $(39 \%)$, vegetation consumption $(40 \%)$, cow milk $(12 \%)$, and meat $(8 \%)$. 
Table 4. 1996 Airborne Pathway Doses from SRS Releases Using

Consumption of Cow Milk Pathway (a)

By Pathway

\begin{tabular}{|c|c|c|c|c|}
\hline & \multicolumn{2}{|c|}{ Maximally Exposed Individual } & \multicolumn{2}{|c|}{ Collective Dose } \\
\hline & $\begin{array}{c}\text { Max. Ind. } \\
\text { Dose (mrem) }\end{array}$ & $\begin{array}{l}\text { Percent of } \\
\text { Total Dose }\end{array}$ & $\begin{array}{c}\text { Pop. Dose } \\
\text { (person-rem) }\end{array}$ & $\begin{array}{l}\text { Percent of } \\
\text { Total Dose }\end{array}$ \\
\hline Plume & $1.72 \mathrm{E}-05$ & 0.03 & $1.60 \mathrm{E}-03$ & 0.06 \\
\hline Ground & 8.74E-04 & 1.63 & 7.03E-02 & 2.51 \\
\hline Inhalation & $2.06 \mathrm{E}-02$ & 38.50 & $1.86 \mathrm{E}+00$ & 66.43 \\
\hline Vegetation & $2.14 \mathrm{E}-02$ & 39.99 & $5.40 \mathrm{E}-01$ & 19.29 \\
\hline Cow Milk & $6.22 \mathrm{E}-03$ & 11.62 & $2.36 \mathrm{E}-01$ & 8.43 \\
\hline Meat & 4.40E-03 & 8.22 & $9.21 \mathrm{E}-02$ & 3.29 \\
\hline Total & 5.35E-02 & & $2.80 \mathrm{E}+00$ & \\
\hline
\end{tabular}

By Radionuclide (b)

Gases and Vapors

$\begin{array}{lcccc}\text { H-3 } & 3.64 \mathrm{E}-02 & 68.01 & 2.09 \mathrm{E}+00 & 74.64 \\ \mathrm{C}-14 & 2.30 \mathrm{E}-03 & 4.30 & 8.53 \mathrm{E}-02 & 3.05 \\ \mathrm{Kr}-85 & 1.72 \mathrm{E}-05 & 0.03 & 1.60 \mathrm{E}-03 & 0.06 \\ \mathrm{I}-129 & 5.87 \mathrm{E}-03 & 10.97 & 1.94 \mathrm{E}-01 & 6.93\end{array}$

Particulates

$\begin{array}{lllll}\text { Sr-90 } & 3.39 \mathrm{E}-04 & 0.63 & 5.80 \mathrm{E}-03 & 0.21 \\ \text { Ru-106 } & 2.68 \mathrm{E}-03 & 5.01 & 6.25 \mathrm{E}-02 & 2.23 \\ \text { Cs-137 } & 7.82 \mathrm{E}-04 & 1.46 & 5.28 \mathrm{E}-02 & 1.89 \\ \text { U-234 } & 1.15 \mathrm{E}-04 & 0.21 & 1.15 \mathrm{E}-02 & 0.41 \\ \text { U-235 } & 5.62 \mathrm{E}-05 & 0.11 & 4.46 \mathrm{E}-03 & 0.16 \\ \text { U-238 } & 5.84 \mathrm{E}-04 & 1.09 & 5.80 \mathrm{E}-02 & 2.07 \\ \text { Pu-238 } & 1.25 \mathrm{E}-03 & 2.34 & 9.09 \mathrm{E}-02 & 3.25 \\ \text { Pu-239 } & 2.67 \mathrm{E}-03 & 4.99 & 1.17 \mathrm{E}-01 & 4.18 \\ \text { Am-241 } & 3.99 \mathrm{E}-05 & 0.07 & 2.82 \mathrm{E}-03 & 0.10 \\ \text { Cm-244 } & 3.30 \mathrm{E}-04 & 0.62 & 3.82 \mathrm{E}-03 & 0.14 \\ \text { Am-243 } & 8.65 \mathrm{E}-05 & 0.16 & 1.47 \mathrm{E}-02 & 0.53 \\ & & & & \end{array}$

a. Committed effective dose equivalent.

b. Radionuclides contributing $0.01 \%$ or more of the total dose. 
For 1996, the MAXIGASP code determined that the west-southwest sector of the site (near D-Area) was the location of the airborne pathway maximally-exposed-individual.

A 10-year history of airborne pathway maximally-exposed-individual doses is shown in Figure 8. As can be seen, the doses generally decreased during the past 10 years, corresponding to the shutdown of the site's reactors and to the continued decreases in atmospheric tritium oxide releases due to changes in the site's mission (Figure 1).

Additional calculations of the dose to the maximally exposed individual were performed substituting a goat milk pathway for the usual cow milk pathway. The potential dose using goat milk was estimated at $0.06 \mathrm{mrem}$, which is slightly more than the cow milk pathway.

Most of this difference is from tritium oxide because the transfer factor (fraction of the daily intake of the nuclide that appears in each liter of milk) for tritium is 17 times higher for goat milk than for cow milk (NRC, 1977). However, because goat milk consumption is less common, the dose calculated from cow milk consumption continues to be the primary dose used by SRS for demonstrating compliance with dose standards.

\section{Collective Dose}

Potential doses also are calculated, by pathway and radionuclide, using the POPGASP code for the population $(620,100$ people) within 80 kilometers of SRS.

The 1996 collective air pathway dose was estimated to be 2.8 person-rem, which is less than $0.01 \%$ of the collective dose received from natural sources of radiation (about 186,000 person-rem). The 1996 collective dose was about $20 \%$ less than the 1995 dose of 3.5 person-rem.

As shown in Table 4 , tritium oxide releases accounted for over $74 \%$ of the collective dose. The critical pathways for the population were inhalation $(66 \%)$, ground shine $(2 \%)$, and consumption of 1) vegetation $(19 \%), 2)$ cow milk $(8 \%)$, and meat $(3 \%)$.

A 10-year history of SRS airborne pathway collective doses is presented with the maximally-exposed-individual doses in Figure 8. As shown, collective doses generally have decreased during this period, mirroring the individual dose trend.

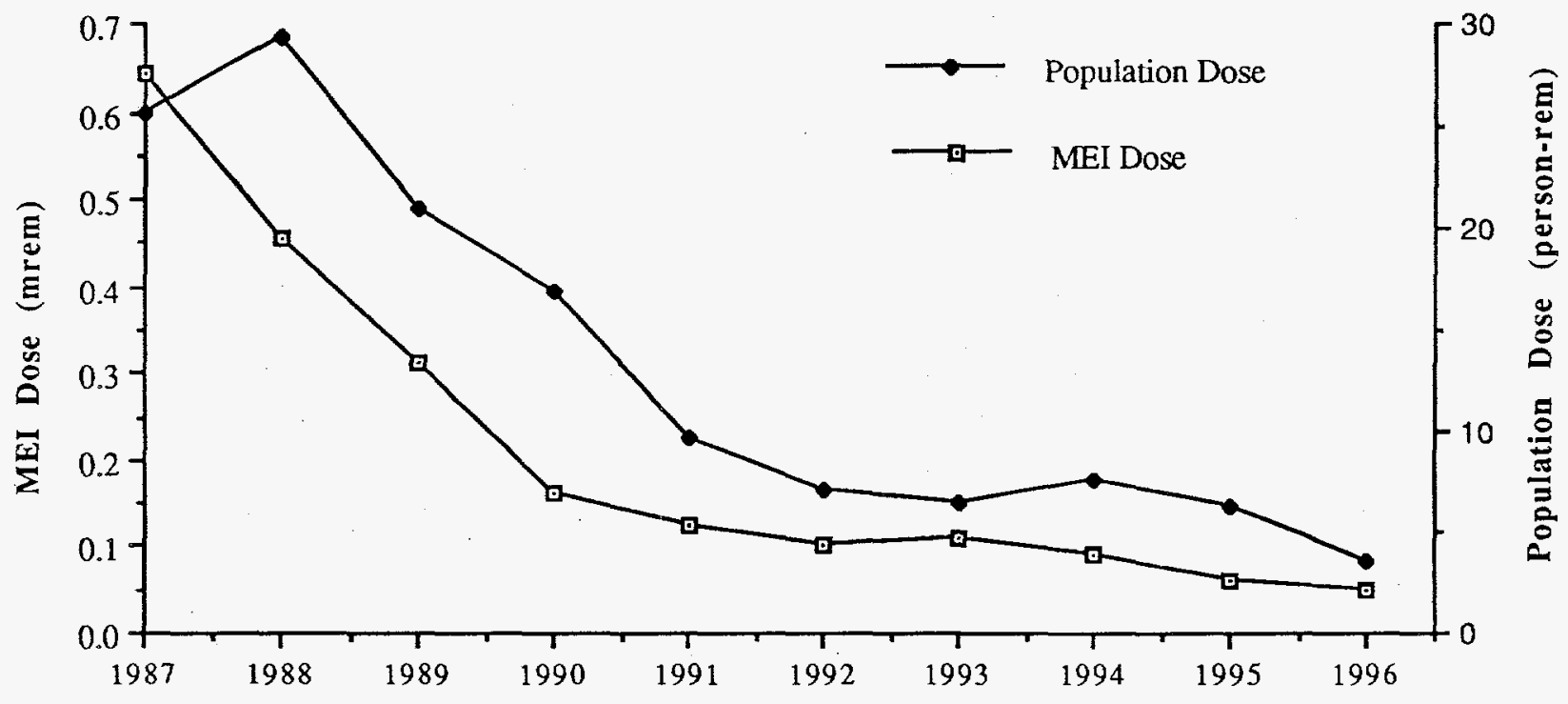

Figure 8. Airborne Pathway MEI and Population Doses (1987-1996) 


\section{LIQUID PATHWAY DOSES}

For SRS radioactive liquid releases, the maximally-exposed-individual and collective doses were estimated using the LADTAPII computer code (Simpson, 1980), which is an NRC code for determining radiation doses to man via aquatic pathways.

\section{Savannah River Radionuclide Concentrations}

Measured concentrations of tritium and cesium-137 in the Savannah River at River Mile 120 (near U.S. Highway 301 bridge) and measured concentrations of tritium at the Beaufort-Jasper and City of Savannah Industrial and Domestic Water Supply Plant (Port Wentworth) water treatment facilities are used directly in SRS dose determinations and model comparisons.

For all other radionuclides released from the site, the LADTAPII code calculates the potential maximum concentrations at the River Mile 120 location and at the water treatment facilities. This is done because most radionuclides are released from the site in such small quantities that they normally cannot be measured in environmental samples, using standard analytical methods.

\section{Tritium}

The 1996 12-month average tritium concentrations measured at Savannah River Mile $120(1.2 \mathrm{pCi} / \mathrm{mL})$ and in the drinking water at Beaufort-Jasper $(0.92 \mathrm{pCi} / \mathrm{mL})$ and Port Wentworth $(0.99 \mathrm{pCi} / \mathrm{mL})$ remained well below EPA's $20 \mathrm{pCi} / \mathrm{mL}$ (EPA, 1993) concentration standard for public drinking water supplies.

These concentrations are approximately the same as the corresponding 1995 concentrations, even though the amount of tritium oxide released from SRS during 1996 was about $21 \%$ less than during 1995 (Figure 4). This was because the Savannah River's effective flow rate was about 13\% less in 1996 than in 1995, causing less dilution to occur.

The 1987-1996 annual average tritium concentrations measured at River Mile 120 and at the Beaufort-Jasper and Port Wentworth treatment plants are compared to the EPA drinking water standard for tritium (20 $\mathrm{pCi} / \mathrm{mL}$ ) in Figure 9. The data shown for the Beaufort-Jasper and Port Wentworth treatment plants are the tritium concentrations measured in the finished drinking water at each facility.

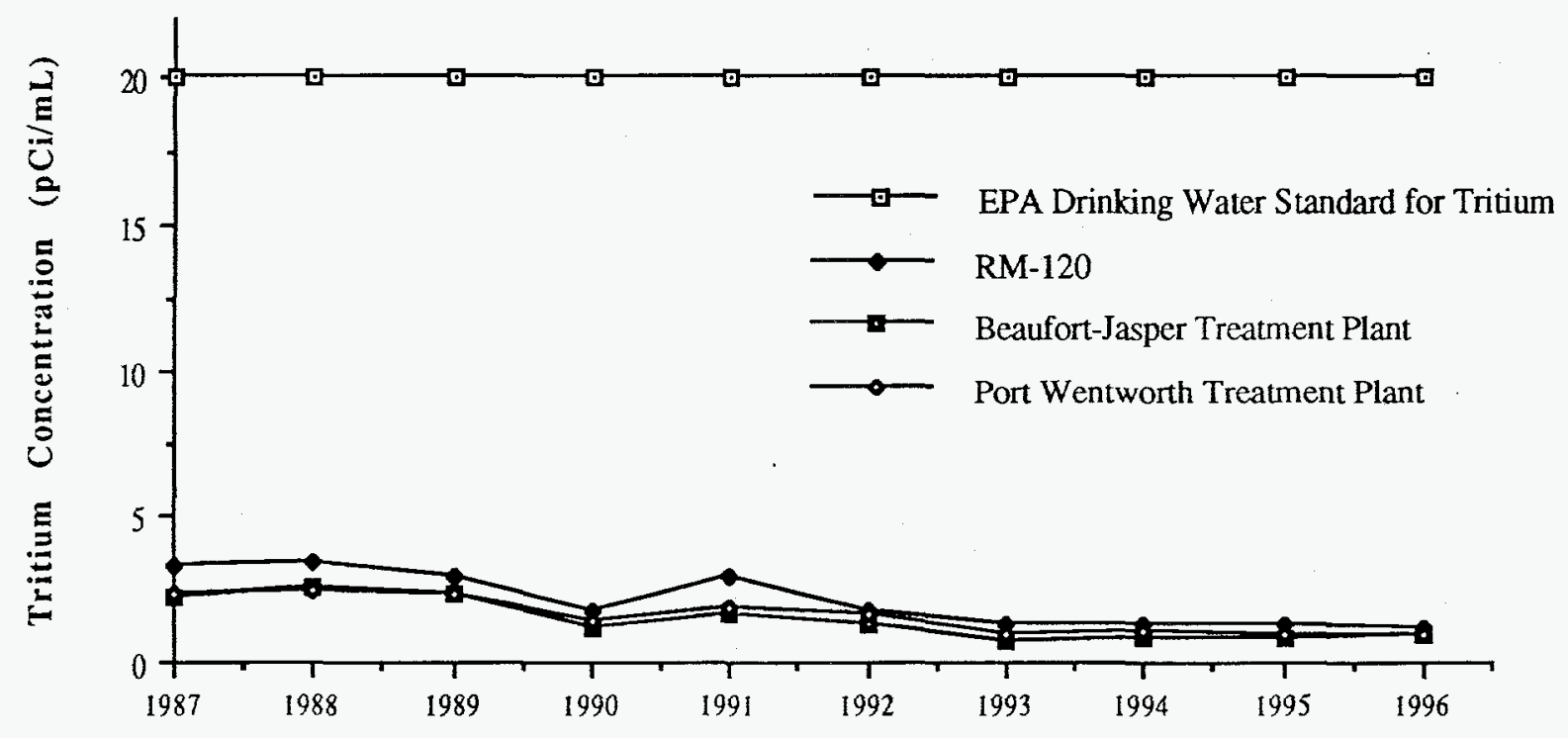

Figure 9. Annual Average Tritium Concentrations at River Mile 120, Beaufort Jasper, and Port Wentworth Compared to EPA's Drinking Water Standard for Tritium 


\section{Cesium-137}

For the element cesium (including radioactive isotopes of cesium), the site-specific bioaccumulation factor for Savannah River fish is 3,000 (Hamby, 1991). That is, the concentration of cesium in fish flesh is about 3,000 times greater than the concentration of cesium in the water in which the fish live. Because of this high bioaccumulation factor, cesium-137 is more easily detectable in fish flesh than in river water. Therefore, the fishpathway dose from cesium-137 is based directly on radioanalysis of the fish collected from River Mile 120, which is the assumed location of the maximally exposed individual. The fish pathway dose from all other released radionuclides is based on the calculated concentrations determined by LADTAPII.

In 1996, the weighted-average concentration (based on the number of composites analyzed) of cesium-137 in River Mile 120 fish was about $0.060 \mathrm{pCi} / \mathrm{g}$. This was about $12 \%$ less than the 1995 average of $0.068 \mathrm{pCi} / \mathrm{g}$.

\section{Potential Liquid Pathway Doses}

The 1996 potential liquid pathway doses from SRS releases are shown in Tables 5 and 6 by pathway and by radionuclide (Arnett, 1997).

\section{Maximally-Exposed-Individual Dose}

The maximum potential liquid pathway dose is calculated based on annual average radionuclide concentrations in river water and is determined for an individual who, on an annual basis, drinks 2 liters per day of untreated river water, consumes 19 kilograms of fish, and spends many hours swimming, fishing, and boating on the river. In 1996, the potential dose to the maximally exposed individual was 0.14 mrem, which is $0.14 \%$ of the DOE dose standard of 100 mrem per year.

As shown in Table 5, approximately $43 \%$ of the liquid pathway dose resulted from the ingestion of cesium-137 in fish, and about $40 \%$ resulted from the ingestion (via drinking water) of tritium. The fish (47\%) and water (53\%) consumption pathways accounted for nearly all of the liquid pathway dose.

A 10-year history of maximally-exposedindividual doses is shown in Figure 10. The doses have generally decreased during this time, corresponding to decreases in releases of tritium (Figure 4) and cesium-137 (Figure 5). However, the 1996 dose remained about the same as the 1995 dose-even though the amount of tritium oxide released from the site decreased during 1996-mainly because the Savannah River's effective annual flow rate decreased, causing less dilution to occur.

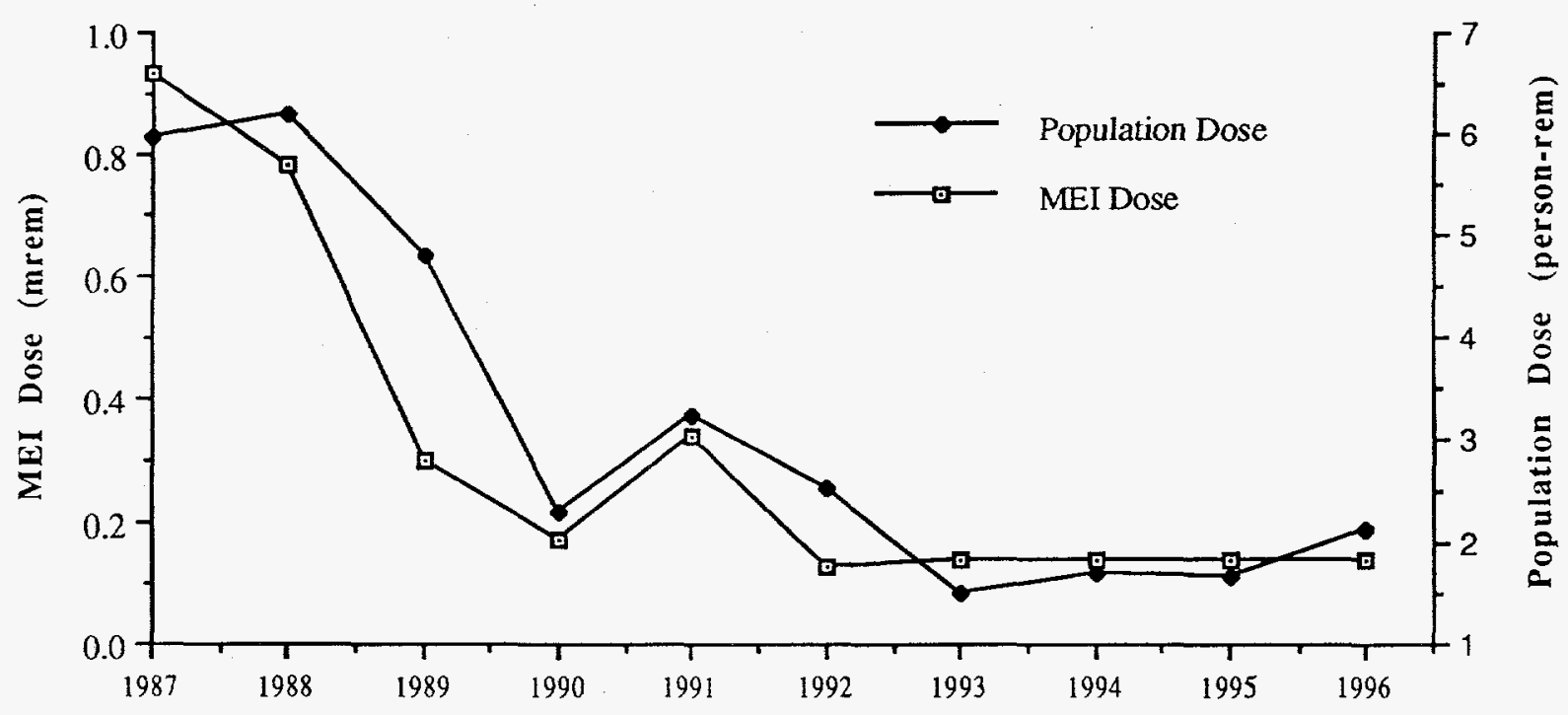

Figure 10. Liquid Pathway MEI and Population Doses 
Table 5. 1996 Liquid Pathway Doses from SRS Releases (a)

By Pathway

Maximally Exposed Individual

\begin{tabular}{cc}
\hline Dose & Percent of \\
(mrem) & Total Dose
\end{tabular}

$\begin{array}{lcc}\text { Fish } & 6.29 \mathrm{E}-02 & 46.70 \\ \text { Water } & 7.16 \mathrm{E}-02 & 53.16 \\ \text { Shoreline } & 1.97 \mathrm{E}-04 & 0.15 \\ \text { Swimming } & 1.28 \mathrm{E}-07 & <0.01 \\ \text { Boating } & 1.51 \mathrm{E}-07 & <0.01\end{array}$

Total

1.35E-01

By Radionuclide

Maximally Exposed Individual

$\begin{array}{cc}\text { Dose } & \text { Percent of } \\ \text { (mrem) } & \text { Total Dose }\end{array}$

H-3

5.45E-02

Sr-90

$5.71 \mathrm{E}-03$

$2.89 \mathrm{E}-03$

$5.82 \mathrm{E}-02$

$7.10 \mathrm{E}-08$

2.12E-04

$5.76 \mathrm{E}-06$

$2.40 \mathrm{E}-04$

$1.09 \mathrm{E}-03$

$1.19 \mathrm{E}-02$

$5.00 \mathrm{E}-05$

$4.48 \mathrm{E}-06$

$1: 35 E-01$

Am-241

Cm-244

Total

a. Committed effective dose equivalent.
Collective Dose

$\begin{array}{cc}\begin{array}{c}\text { Pop. Dose } \\ \text { (person-rem) }\end{array} & \begin{array}{c}\text { Percent of } \\ \text { Total Dose }\end{array}\end{array}$

Sport Fish

1.14E-01

5.29

Commercial Fish

$1.11 \mathrm{E}-03$

0.05

Beaufort-Jasper

$1.72 \mathrm{E}+00$

79.89

Port Wentworth

3.09E-01

14.35

Marine Invertebrates

7.32E-04

0.03

Recreation-River

8.21E-03

0.38

Total

$2.15 E+00$

40.46

Collective Dose

$\begin{array}{cc}\text { Pop. Dose } & \text { Percent of } \\ \text { (person-rem) } & \text { Total Dose }\end{array}$

H-3

$1.51 \mathrm{E}+00$

70.19

Sr-90

9.55E-02

4.43

I-129

6.03E-02

2.80

Cs-137

1.33E-01

6.20

Pm-147

$1.28 \mathrm{E}-06$

$<0.01$

U-234

$5.72 \mathrm{E}-03$

0.27

U-235

U-238

Pu-238

$1.57 \mathrm{E}-04$

0.01

0.18

0.81

8.81

0.04

$<0.01$

Pu-239

Am-241

$6.50 \mathrm{E}-03$

0.30

$2.86 \mathrm{E}-02$

1.33

3.11E-01

14.43

9.03E-04

0.04

Cm-244

8.27E-05

$<0.01$

Total

$2.15 E+00$ 
Table 6. 1996 Maximally Exposed Individual Dose from Public Water Supplies Below SRS

\section{Beaufort-Jasper}

Radionuclide

\section{H-3}

Sr-90

I-129

Cs-137

Pm-147

U-234

U-235

U-238

Pu-238

Pu-239

Am-241

Cm-244

Total

\section{Port Wentworth}

Radionuclide

H-3 (oxide)

Sr-90

I-129

Cs-137

Pm-147

U-234

U-235

U-238

Pu-238

Pu-239

Am-241

Cm-244

Total
Maximally Exposed

Individual Dose, (mrem) (a)

4.21E-02

2.54E-03

$1.64 \mathrm{E}-03$

$5.77 \mathrm{E}-04$

$3.40 \mathrm{E}-08$

$1.59 \mathrm{E}-04$

$4.26 \mathrm{E}-06$

$1.81 \mathrm{E}-04$

$7.92 \mathrm{E}-04$

$8.60 \mathrm{E}-03$

$2.39 \mathrm{E}-05$

$2.20 \mathrm{E}-06$

$5.66 \mathrm{E}-02$
Percent of Total Dose
74.40
4.48
2.89
1.02
$<0.00$
0.28
0.01
0.32
1.40
15.20
0.04
$<0.01$ 


\section{Drinking Water Dose}

The maximally-exposed-individual dose to a person consuming drinking water processed by the Beaufort-Jasper and Port Wentworth water treatment plants was calculated using annual average radionuclide concentrations in the finished drinking water and a maximum consumption rate of 2 liters per day for a year.

For the Beaufort-Jasper plant, the potential maximum dose during 1996 was $0.06 \mathrm{mrem}$; for the Port Wentworth plant, the potential dose also was $0.06 \mathrm{mrem}$. This dose is $1.5 \%$ of the DOE and EPA standard of 4 mrem per year from public water supplies. The 1996 maximum potential drinking water dose was slightly more than the 1995 maximum dose of $0.05 \mathrm{mrem}$. This increase is mainly attributed to the decrease in effective Savannah River flow during 1996. A 10-year history of the maximum potential drinking water doses is shown in Figure 11. The doses have generally decreased during this time, corresponding to decreases in releases of tritium (Figure 4).

As shown in Table 6, tritium accounts for nearly $75 \%$ of the downriver drinking water dose at both of the treatment plants. Plutonium-239 (15\%), strontium-90 (4\%), iodine-129 (3\%), plutonium-238 (1\%), and cesium-137 (1\%) accounted for most of the remainder of the maximum potential drinking water doses for 1996.

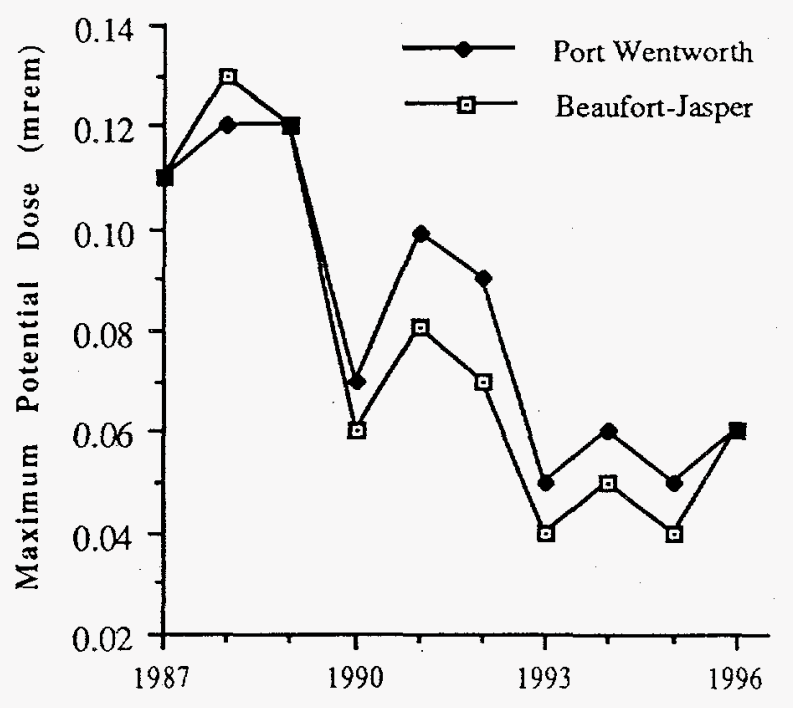

Figure 11. Drinking Water Doses (1987-1996)

\section{Liquid Pathwav Collective Dose}

The SRS liquid pathway collective dose was calculated for several population groups. One group uses the Savannah River for recreational purposes; one group consumes sport and commercial fish; and one group drinks treated river water from the Beaufort-Jasper or Port Wentworth public water systems. Table 5 shows the collective dose to Savannah River users by pathway and by radionuclide.

In 1996, the collective dose from SRS liquid releases was 2.2 person-rem, which is less than $0.01 \%$ of the collective dose received from natural sources of radiation (about 186,000 person-rem). The 1996 collective dose was about $29 \%$ more than the 1995 dose of 1.7 person-rem. This increase in dose is attributed to the decrease in effective Savannah River flow during 1996 and to the increase in plutonium-239 releases (Figure 6).

A 10-year history of SRS liquid pathway collective doses is shown with the maximallyexposed-individual doses in Figure 10. Collective doses generally decreased during this time, mirroring the individual dose trend.

As shown in Table 5 , over $94 \%$ of the collective dose can be attributed to the drinking water pathway. Because this pathway dominates the collective dose, tritium $(70 \%)$ is the dominant radionuclide. Other significant contributors to the collective dose were plutonium-239 (14\%), cesium-137 (6\%), strontium-90 (4\%), iodine-129 (3\%), and plutonium-238 (1\%).

\section{ALL PATHWAY DOSE}

To demonstrate compliance with DOE's allpathway dose standard of 100 mrem per year, SRS conservatively combines the maximallyexposed-individual air pathway and liquid pathway dose estimates, even though the two doses are calculated for hypothetical individuals residing at different locations.

For 1996, the potential maximally-exposedindividual all-pathway dose was $0.19 \mathrm{mrem}$ (0.05 mrem from air pathways and $0.14 \mathrm{mrem}$ from liquid pathways). This dose is $0.19 \%$ of DOE's all-pathway standard. Figure 12 shows a 10-year history of SRS's all-pathway doses. The 1996 dose was about 5\% less than the 1995 dose, mainly because of decreases in airborne tritium oxide releases during 1996. 


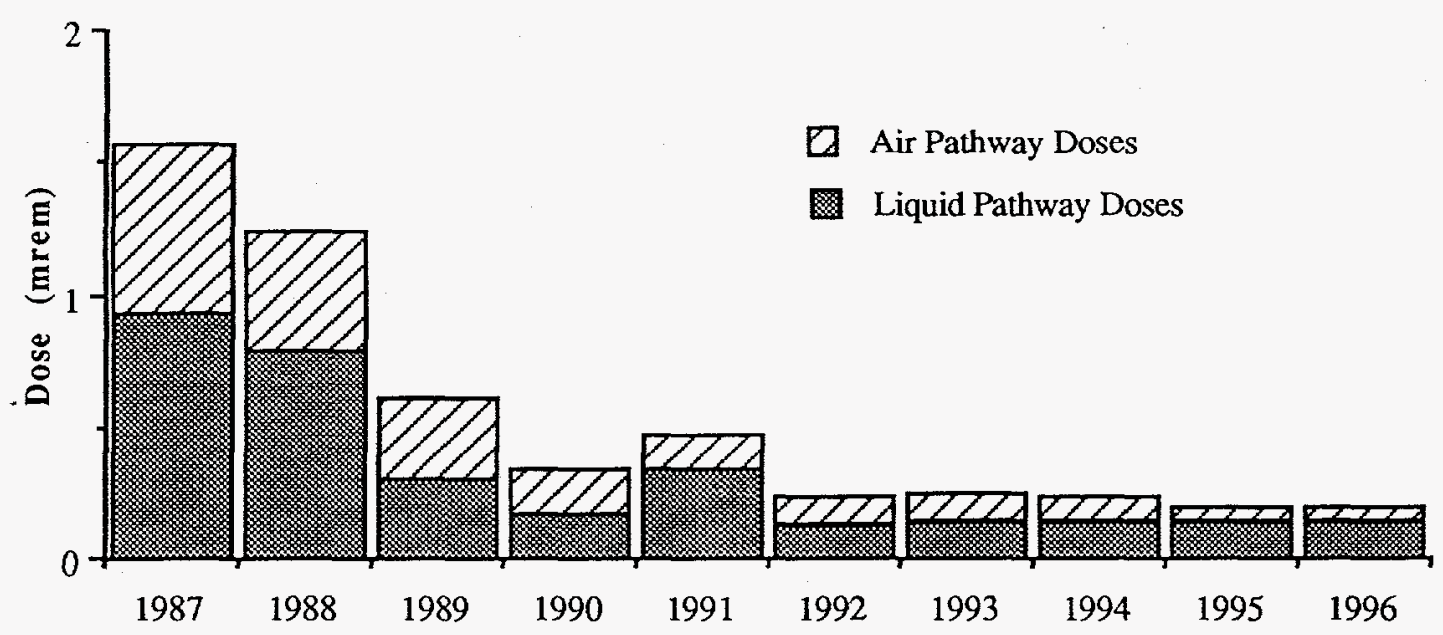

Figure 12. Ten-Year History of SRS Maximum Potential All Pathway Doses

\section{RISK ASSESSMENT}

At low doses (below 10,000 mrem), the effects of radiation in the human population cannot be measured directly and the probability of any effects occurring is small. This makes it especially difficult to interpret and communicate the risks associated with very low radiation doses (less than 100 mrem). However, several approaches can be used in an attempt to relate small doses to potential risks.

Method 1: compare the SRS dose to regulatory standards, which has been done throughout this report. As stated previously, SRS's 1996 potential all-pathway dose of 0.19 mrem is just $0.19 \%$ of DOE's all-pathway standard of $100 \mathrm{mrem}$ per year. There are no regulatory standards for collective doses.

Method 2: compare the SRS dose to the naturally occurring background radiation dose received by an average individual in the U.S., which is about 300 mrem per year (NCRP, 1987). The SRS all-pathway dose of 0.19 mrem is just $0.06 \%$ of this background dose.

For the collective dose, the population within 80 kilometers of SRS $(620,100)$ receive a naturally occurring background collective dose of about 186,000 person-rem per year. In 1996, the total collective dose potentially caused by SRS radioactive releases -was 5.0 person-rem (2.8 from the air pathway and 2.2 from the liquid pathway), which is just $0.003 \%$ of the background collective dose.

Method 3: compare the all-pathway dose to a common voluntary action that is known to cause an additional radiation dose, such as air travel. The cosmic ray dose received by a person on a round trip flight from New York to Los Angeles is approximately $5 \mathrm{mrem}$ (NCRP, 1987). SRS's 1996 all-pathway dose of 0.19 mrem is just $3.8 \%$ of this dose.

Method 4: determine the total, lifetime, stochastic risk from the SRS dose by using the total risk coefficient developed by the International Commission on Radiological Protection (ICRP) in its Publication 60 (ICRP, 1990). The ICRP-60 factor, which is 7.3E-07 per mrem, includes factors for

$\begin{array}{ll}\text { - fatal cancers } & \text { (5.0E-07 per mrem) } \\ \text { - non-fatal cancers } & \text { (1.0E-07 per mrem) } \\ \text { - hereditary effects } & \text { (1.3E-07 per mrem) }\end{array}$

Therefore, the potential lifetime stochastic risk of severe detriment from SRS's all-pathway dose of 0.19 mrem would be $1.4 \mathrm{E}-07$. Stated another way, if a group of $1,000,000$ people each received a radiation dose of $0.19 \mathrm{mrem}$ during their collective lifetimes there would theoretically be less than $1(0.14)$ additional severe detriment. This is a small risk compared to the 200,000 or more expected fatal cancers from other causes during their lifetimes (BEIR $\mathrm{V}, 1990)$. 


\section{REFERENCES}

Arnett, M.W., and A.R. Mamatey, Savannah River Site Environmental Report for 1996, WSRC-TR-97-0171, Savannah River Site, Aiken, SC, 1997.

BEIR V, Health Effects of Expose to Low Levels of Ionizing Radiation, National Research Council Report, Washington, D.C., 1990.

Eckerman, K.F., F.J. Congel, A.K. Roecklein, and W.J. Pasciak. Users Guide to GASPAR Code. NUREG0597, U.S. Nuclear Regulatory Commission, Washington, D.C., 1980.

Hamby, D.M., Land and Water Use Characteristics in the Vicinity of the Savannah River Site, WSRC-RP-91-017, Savannah River Technology Center, Aiken, SC, 1991.

International Commission on Radiological Protection. Recommendations of the ICRP, Publication 60, Elmsford, NY, 1990.

Kantelo, M.V., Summary of I-129 Measurements in the Ground and Surface Water, DPST-87-820, Savannah River Technology Center, Aiken, SC, 1987.

Kantelo, M.V. and B.S. Crandall, The Legacy of Cf-252 Operations at SRS $(U)$, WSRC-MS-92-379, Savannah River Technology Center, Aiken, SC, 1993.

National Council on Radiation Protection and Measurements, Ionizing Radiation Exposure of the Population of the United States, NCRP Report No. 93, Bethesda, MD, 1993.

Parker, M.J. et al, The 1987-1991 Savannah River Site Meteorological Data Base (U), WSRC-RP-92-598, Savannah River Technology Center, Aiken SC, 1992.
Sagendorf, J.F., J.T. Croll, and W.F. Sendusky. XOQDOQ: Computer Program for the Meteorological Evaluation of Routine Effluent Releases at Nuclear Power Stations. NUREG/CR2919, U.S. Nuclear Regulatory Commission, Washington, D.C., 1982.

Simpson, K.F., and B.L. McGill, Users Manual for LADTAP II - A Computer Program for Calculating Radiation Exposure to Man from Routine Release of Nuclear Reactor Liquid Effluents. NUREG/CR1276(ORNL/NUREG/TOC1), Oak Ridge National Laboratory, Oak Ridge, TN, 1980.

U.S. Environmental Protection Agency, National Primary Drinking Water Regulations, Title 40, Code of Federal Regulations, Part 141, Washington, D.C., 1993.

U.S. Nuclear Regulatory Commission, Calculation of Annual Doses to Man from Routine Releases of Reactor Effluents for the Purpose of Evaluating Compliance with 10 CFR 50, Appendix I, Regulatory Guide 1.109, Washington, D.C., 1977. 